\title{
As Ordens Militares em combate nos finais da Idade Média: o caso da Guerra da Sucessão de Castela (1475-1479)
}

Military Orders in confrontation during the transition from the Middle Ages to Modernity: War of the Castilian Succession (1475-1479)

\section{António Carlos Martins Costa}

\section{OpenEdition}

\section{Journals}

\section{Edição electrónica}

URL: http://journals.openedition.org/medievalista/1007

DOI: $10.4000 /$ medievalista. 1007

ISSN: $1646-740 \mathrm{X}$

\section{Editora}

Instituto de Estudos Medievais - FCSH-UNL

\section{Refêrencia eletrónica}

António Carlos Martins Costa, «As Ordens Militares em combate nos finais da Idade Média: o caso da Guerra da Sucessão de Castela (1475-1479) », Medievalista [Online], 19 | 2016, posto online no dia 01 junho 2016, consultado no dia 19 abril 2019. URL : http://journals.openedition.org/medievalista/1007 ; DOI : 10.4000/medievalista.1007

\section{(C) IEM}


Título: As Ordens Militares em combate nos finais da Idade Média: o caso da Guerra da Sucessão de Castela (1475-1479) I Military Orders in confrontation during the transition from the Middle Ages to Modernity: War of the Castilian Succession (1475-1479)

Autor: António Carlos Martins Costa

Universidade: Universidade de Coimbra

Faculdade e Departamento / Unidade de Investigação: Faculdade de Letras / Centro de

História da Sociedade e da Cultura / Centro de História da Universidade de Lisboa

Código Postal: 3004-530

Cidade: Coimbra

País: Portugal

Contacto: antonio.cc.86@gmail.com

Fonte: Medievalista [Em linha]. Dir. Bernardo Vasconcelos e Sousa. Lisboa: IEM.

Disponível em:

http://www2.fcsh.unl.pt/iem/medievalista/MEDIEVALISTA19/costa1907.html

ISSN: 1646-740X

Data recepção do artigo: 28 de Março de 2013

Data aceitação do artigo: 27 de Julho de 2015

\section{Resumo}

Nos finais do século XV, longe ia o contexto do aparecimento das Ordens Militares, ocorrido na Idade Média Plena, quando os cluniacenses difundiam o ideal de um monaquismo vigoroso, a cavalaria se estabelecia enquanto grupo cristianizado e a Cruzada procurava a libertação dos lugares santos e o afastamento da ameaça islâmica sobre a Cristandade. No quadro peninsular, onde estas milícias se estabeleceram desde o século XII para combater os muçulmanos na Reconquista, conseguimos observar na charneira para a modernidade a sua faceta marcial, nem sempre considerada pela historiografia para esse tempo de transição bélica. Tomando por objecto a Guerra da 
Sucessão de Castela de 1475-1479, procuraremos compreender - com base em fontes portuguesas, castelhanas e aragonesas - o papel (activo) que as Ordens Militares assumiram nos preparativos e nas operações da campanha que D. Afonso V conduziu no reino vizinho, com ponto alto na Batalha de Toro (1476), bem como na defesa da raia portuguesa; na Castela dos Reis Católicos, caracterizadas pela volatilidade de posições e pela conflitualidade interna, estas milícias protagonizaram, como veremos, as mais diversas acções militares, revelando-se determinantes na evolução da contenda.

Palavras-chave: História Militar Medieval; Ordens Militares; Batalha de Toro; D. Afonso V de Portugal; Reis Católicos.

\section{Abstract}

In the late fifteenth century, distant was the context of the emergence of the Military Orders, which occurred in the Classic Middle Ages, when Cluny diffused the ideal of a strong monasticism, chivalry was established as christianized group and the Crusade sought the freedom of holy places and the removal Islamic threat about Christianity. Within the peninsular area, where these militias were established since the twelfth century to fight the Muslims in the Reconquista, we can look at the hinge to modernity his martial aspect, not always considered by historiography for this time of transitions at war. Taking in account the War of Succession of Castile 1475-1479, we seek to understand - based on portuguese, castilian and aragonese sources - the (active) role assumed by the Military Orders on the preparations and on the operations of the campaign led by Afonso $\mathrm{V}$ at the neighboring kingdom, with a high point in the Battle of Toro (1476), as well as the defense of the portuguese frontier; and the actions on the Castile of the Catholic Kings, characterized by volatility positions and internal conflict, these militias staged, as we shall see, various military actions, revealing determinants in the evolution of strife.

Keywords: Medieval Military History; Military Orders; Battle of Toro; Afonso V of Portugal; Catholic Kings.

Medievalista online № 19| Janeiro - Junho 2016 (C) IEM - Instituto de Estudos Medievais 2 


\title{
As Ordens Militares em combate na transição da Idade Média para a Modernidade: o caso da Guerra da Sucessão de Castela (1475-1479)
}

\author{
António Carlos Martins Costa
}

"Relativamente às Ordens Militares será bom começar por advertir o leitor para o facto de o termo da Reconquista e a delimitação quase definitiva das fronteiras do território português que se lhe seguiu, em finais do século XIII, não terem significado um esvaziamento total da sua função militar."1

\section{Nota prévia}

Chegadas à Península Ibérica pouco após a sua fundação na Terra Santa, quando a marca cristã se encontrava próxima do Sistema Central, as Ordens Militares² tornaramse amplamente conhecidas pelo seu papel na dinâmica de Reconquista entre os séculos XII e XIV, quando o imenso território islâmico acabou resumido ao pequeno reino de Granada. Nesse período, estas milícias encontraram na Hispânia um espaço vital privilegiado, ao invés do que sucedia na Palestina com o insucesso cruzadístico, pelo que aos hospitalários e templários se juntaram Ordens de origem ibérica como Santiago,

\footnotetext{
${ }^{1}$ MONTEIRO, João Gouveia - "Organização e formação militares". in BARATA, Manuel Themudo e TEIXEIRA, Nuno Severiano (dir.) - Nova História Militar de Portugal. Vol. 1. Mem Martins: Círculo de Leitores, 2003, p. 200.

${ }^{2}$ Leia-se, numa perspectiva panorâmica, a propósito das Ordens Religiosas Militares: AYALA MARTÍNEZ, Carlos, NOVOA PORTELA, Feliciano (dir.) - As Ordens Militares na Europa Medieval. Trad. Daniel Gouveia. Lisboa: Chaves Ferreira, 2005.
}

Medievalista online № 19| Janeiro - Junho 2016 (C) IEM - Instituto de Estudos Medievais 3 
Calatrava e Alcântara ${ }^{3}$. Com enquadramento religioso, os freires cavaleiros apresentavam-se fortemente organizados, hierarquizados e disciplinados, exibindo uma eficácia militar que lhes assegurou concessões de vastos territórios e abundantes rendas nos reinos cristãos ${ }^{4}$.

Observando a realidade portuguesa, a centúria de Quatrocentos correspondeu a um momento de transformação institucional das Ordens Militares, como mostraram as alterações estatutárias que permitiram aos cavaleiros de Cristo, Avis e Santiago contrair matrimónio, mas também de clara polarização em torno da Coroa, uma vez que os monarcas procuraram atrair para a sua órbita estas milícias pela sua importância económica, social e militar ${ }^{5}$. Mas, finda a Reconquista do território e cristalizada a fronteira portuguesa, mantiveram as Ordens Militares o seu protagonismo marcial até à viragem para a modernidade? A Guerra da Sucessão de Castela de 1475-1479 reveste-se de particular interesse de estudo ao inscrever-se num profícuo contexto de transformações bélicas. A teoria da «Revolução Militar», inicialmente proposta por Michel Roberts em 1955, destaca o crescimento do tamanho dos exércitos e o aumento da duração das campanhas, a introdução das armas de fogo e o destronar da cavalaria como núcleo principal dos exércitos ${ }^{6}$.

O conflito que opôs D. Afonso V aos Reis Católicos permite-nos, portanto, observar o papel marcial das Ordens Militares portuguesas num período de transição, quer no âmbito de um exército de campanha, quer no quadro da defesa do território; quanto a Castela, procuraremos alcançar o seu protagonismo militar, num contexto de fractura

\footnotetext{
${ }^{3}$ No que toca às milícias monástico-militares hispânicas, leia-se: AYALA MARTíNEZ, Carlos de - Las órdenes militares hispánicas en la Edad Media (siglos XII-XV). Madrid: Marcial Pons / Latorre Literaria, 2010.

${ }^{4}$ A respeito do papel marcial das Ordens Militares na Reconquista, veja-se: FOREY, Alan - "The Military Orders and the Spanish Reconquest in twelfth and thirtheenth centuries". in Traditio 40 (1984), pp. 197-234; JOSSERAND, Philippe - "Un corps d'armée spécialisé au service de la Reconquête. Les ordres militaires dans le royaume de Castille (1252-1369) ". in.Bulletin de la Société Archéologique et Historique de Nantes et de Loire-Atlantique 137 (2002), pp. 193-214.

${ }^{5}$ FONSECA, Luís Adão da - "Ordens Militares". in AZEVEDO, Carlos Moreira (dir.) - Dicionário da História Religiosa de Portugal. Vol. 3. Lisboa: Círculo de Leitores, 2001, p. 335; OLIVEIRA, Luís Filipe - "Apresentação de Tese A Coroa, os Mestres e os Comendadores: as Ordens Militares de Avis e de Santiago (1330-1449). Tese de Doutoramento em História Medieval". Medievalista [online]. $\mathrm{N}^{\circ} 5$ (Dezembro 2008), pp. 3-5.

${ }^{6}$ Michael Roberts, citado por DUARTE, Luís Miguel - "1449-1495: o triunfo da pólvora". in BARATA, Manuel Themudo e TEIXEIRA, Nuno Severiano (dir.) - Nova História Militar de Portugal. Vol. 1, p. 347.
}

Medievalista online $N^{\circ} 19 \mid$ Janeiro - Junho 2016 @ IEM - Instituto de Estudos Medievais 4 
sociopolítica. Como tal, recorremos a fontes narrativas que cobrem aqueles reinados, como a cronística dos portugueses Rui de Pina ${ }^{7}$, Garcia de Resende ${ }^{8}$ e Damião de Góis ${ }^{9}$, a dos castelhanos Fernando del Pulgar ${ }^{10}$ e Andrés Bernáldez ${ }^{11}$, bem como a do aragonês Jerónimo de Zurita ${ }^{12}$. Quanto às fontes documentais, destacamos os registos de Álvaro Lopes de Chaves $^{13}$, secretário régio de $\mathrm{D}$. Afonso $\mathrm{V}$, assim como outros documentos constantes das chancelarias do Africano e dos Reis Católicos. Por fim, não quisemos deixar de recorrer, como fonte iconográfica, ao célebre Livro das Fortalezas ${ }^{14}$ do escudeiro Duarte d'Armas, que em 1509 procedeu ao debuxo dos castelos da fronteira portuguesa.

\section{As Ordens Militares no exército mobilizado}

No final do século $\mathrm{XV}$, a arte da guerra encontrava-se em franca transformação. Ao heterogéneo exército medieval (formado, além dos contingentes das incontornáveis Ordens Militares, pelos corpos da guarda do rei, pelas mesnadas senhoriais, pelas milícias concelhias, por companhias de mercenários e, mesmo, por grupos de homiziados), juntavam-se corpos permanentes de profissionais da guerra, que dominavam o manuseamento de novas armas, as quais, pela sua especificidade, exigiam novos modelos de treino e, mesmo, técnicos experimentados (era o caso dos artilheiros, tidos até como civis, desligados da hierarquia militar). Do modelo medievo de

\footnotetext{
${ }^{7}$ PINA, Rui de - Crónicas de Rui de Pina. Introdução e revisão de M. Lopes de Almeida. Porto: Lello \& Irmão - Editores, 1977.

${ }^{8}$ RESENDE, Garcia de - Crónica de D. João II e Miscelânea. Ed. conforme a de 1798. Introdução de J. Veríssimo Serrão. Lisboa: Imprensa Nacional - Casa da Moeda, 1991.

${ }^{9}$ GOIS, Damião de - Chronica do Prinçipe Dom Ioam. Ed. crítica e comentada de Graça de Almeida Fernandes. Lisboa: Universidade Nova, 1977.

${ }^{10}$ PULGAR, Fernando del - Crónica de los Reyes Católicos. Edición y estúdio por Juan de Mata Carriazo. Vol. 1. Madrid: Espasa-Calpe, 1943.

${ }^{11}$ BERNALDÉZ, Andrés - Historia de los Reyes Católicos D. Fernando y Doña Isabel escrita por el Bachiller Andrés Bernáldez, Cura que fué la villa de los Palácios, y Capellan de D. Diego Deza, Arzobispo de Sevilla. T. 1. Sevilla: Imprenta que fue de J. M. Geofrin, 1869.

12 ZURITA, Jerónimo - Anales de la Corona de Aragon. t. 4. Saragoça: Diego Dormer, Herederos de Pedro Lanaja y Lamarca, 1668.

${ }^{13}$ CHAVES, Álvaro Lopes de - Livro de apontamentos, 1438-1489: Códice 443 da Colecção Pombalina da B. N. L.. Introd. e transcrição de Anastásia Mestrinho Salgado e Abílio José Salgado. Lisboa: Imprensa Nacional - Casa da Moeda, 1983.

${ }^{14}$ ARMAS, Duarte de - Livro das Fortalezas. Introdução de Manuel da Silva Castelo Branco. $3^{\mathrm{a}}$ ed. Lisboa: Arquivo Nacional da Torre do Tombo / Edições Inapa, 2006.
}

Medievalista online № 19| Janeiro - Junho 2016 (c) IEM - Instituto de Estudos Medievais 5 
recrutamento, em que o exército era habitualmente convocado ad hoc para uma dada campanha, caminhava-se para o ressurgimento de exércitos permanentes. A própria natureza dos conflitos, com operações cada vez mais duradouras, favorecia não só essa evolução temporária de serviço como, por exigir ainda maior número de efectivos, viabilizava um crescimento progressivo dos exércitos ${ }^{15}$. Sobre este pano de fundo de continuidades e rupturas na arte da guerra, qual terá sido o papel das Ordens Militares portuguesas no exército que, entre os meados de 1475 e os de 1476, operou sob o comando de D. Afonso V em Castela?

O envolvimento das milícias monástico-militares radicadas em Portugal no conflito luso-castelhano remonta, de acordo com as fontes que dispomos, à sua própria génese, quando em Dezembro de 1474 chegou a Estremoz uma mensagem do marquês de Vilhena comunicando a morte de D. Henrique IV e pedindo a D. Afonso V que entrasse urgentemente em Castela, por forma a casar-se com a princesa D. Joana e, desse modo, ser levantado rei ${ }^{16}$. Então, de acordo com os cronistas Rui de Pina e Damião de Góis, o conselho régio dividiu-se quanto à abertura de uma guerra com os futuros Reis Católicos: por um lado, um grupo em que pontificavam grandes senhores como o duque de Guimarães e primogénito do duque de Bragança, D. Fernando, e o arcebispo de Lisboa, D. Jorge da Costa, que era contrário ao projecto castelhano; por outro, um conjunto entusiasta do conflito em que se destacava o príncipe D. João - afinal o líder das Ordens de Santiago e de Avis ${ }^{17}$-, "desejando que elRey seu Padre com esperança de acrecentar seus Reynos de Portugal, aceitasse, e nom se escusasse do casamento e empresa de Castela"18. Mas enquanto se travavam acesos debates acerca da viabilidade da guerra $^{19}$, um outro conselheiro do rei, o prior do Crato, D. Vasco de Ataíde $^{20}$,

15 COSTA, António Carlos Martins - A Batalha de Toro e as relações entre Portugal e Castela: dimensões políticas e militares na segunda metade do século XV. Tese de Mestrado em História Medieval apresentada à Faculdade de Letras da Universidade de Lisboa. Lisboa: [Policopiado], 2011, pp. 92-101.

${ }^{16}$ GÓIS, Damião de - ob. cit., cap. XLI, p. 100. PINA, Rui de - ob. cit., cap. CLXXIII, p. 829.

${ }^{17}$ O príncipe D. João recebera o governo da Ordem de Avis em 1468, sucedendo ao Condestável D. Pedro, vindo a assumir a liderança da Ordem de Santiago em 1472, após a morte do pequeno duque de Beja, D. João. Tratava-se, segundo Luís Adão da Fonseca, de uma estratégia da Coroa, numa perspectiva centralizadora, para "criar um bloco Avis-Santiago submetido à mesma cabeça" (FONSECA, Luís Adão da - D. João II. [Lisboa]: Círculo de Leitores, 2005, p. 205).

${ }_{18}^{18}$ PINA, Rui de $-o b$. cit, cap. CLXXIII, p. 829.

${ }^{19}$ Quanto à Ordem de Cristo, cujo mestre era então o pequeno Duque D. Diogo de Viseu (contava a sua mãe D. Brites por administradora), desconhece-se a sua participação no Conselho que reuniu em

Medievalista online № 19| Janeiro - Junho 2016 ๑ IEM - Instituto de Estudos Medievais 6 
juntamente com o bispo de Évora, D. Garcia de Meneses, e o camareiro-mor, Lopo de Albuquerque, elaborava um conjunto de pareceres, conforme registado pelo secretário Álvaro Lopes de Chaves, "acerqua das cousas de que ora o dito senhor loguo deuesse de fornecer e prouer assj pera sua ida a Castela se ouuer de ser como pera deffensão e boa guarda [sic] de seus Rejnos em caso que elle lá non haja de hir”,21. Entre vários aspectos bélicos, do recrutamento à importação de armamento $^{22}$, previam-se a vistoria e as reparações necessárias nos castelos costeiros e fronteiriços, conforme veremos mais adiante, acerca dos quais se aludia à importância do provimento com as modernas "artelharias" 23.

Segundo a cronística portuguesa, a chegada de Lopo de Albuquerque a Évora com as certidões de fidelidade dos apoiantes castelhanos de D. Joana, em Janeiro de 1475, foi determinante para desbloquear a decisão acerca da disputa do trono vizinho ${ }^{24}$. Convencido da viabilidade da guerra, D. Afonso V convocou "os Grandes e Senhores Prelados, Fydalgos, e Cavalleiros, e gente outra de seus Reynos" para, passado o mau

Estremoz no final de 1474. Cf. MARTINS, Maria Odete Banha da Fonseca Sequeira - Poder e sociedade: a duquesa de Beja. Tese de Doutoramento em História Medieval apresentada à Faculdade de Letras da Universidade de Lisboa. Lisboa: [Policopiado], 2011, p. 79-80.

${ }^{20}$ Filho de um dos mais célebres seguidores de D. Afonso V na batalha de Alfarrobeira, o conde D. Álvaro da Atouguia, D. Vasco de Ataíde tornou-se prior do Crato em 1453, sucedendo ao seu irmão D. João de Ataíde. Parece ter consolidado a proximidade do clã em relação ao monarca, uma vez que, em 1455, foi um dos padrinhos de baptismo do príncipe D. João. Durante o governo da ordem, D. Álvaro figurou em actos políticos de grande importância, como o encontro de Gibraltar de 1464 entre D. Afonso V e D. Henrique IV, bem como em diversas acções militares, atestando-se a sua participação na conquista de Arzila e na ocupação de Tânger em 1471. Veja-se: VASCONCELLOS, António Maria Falcão Pestana de - Nobreza e Ordens Militares. Relações sociais e de poder (séculos XIV a XVI). 2 Vols. Dissertação de Doutoramento em História Medieval e do Renascimento apresentada à Faculdade de Letras da Universidade do Porto. Porto: [Policopiado], 2008, pp. 35-36.

${ }^{21}$ CHAVES, Álvaro Lopes - ob. cit., p. 52.

${ }^{22}$ Em matéria de recrutamento, advertia-se para a importância, antes da decisão pelo conflito, de um levantamento das pessoas mobilizáveis, dada a "incertidão" a que induziriam então as "mortes pestelenças, desterros e homisios"; quanto aos cavalos, reconhecendo a sua importância na guerra, procurava-se alargar a sua aquisição ao propor-se que os oficiais régios que os não possuíssem perdessem os respectivos cargos. Para equipar o exército, sugeria-se a rápida importação de impressionantes quantidades do mais diverso armamento: da Península Itálica, deveriam chegar 1.000 arneses, 1.000 cobertas e 500 couraças; da Flandres, aconselhava-se a compra de 500 gibanetes, 500 "capacetes com suas babeiras", 200 lanças, 200 "béstas de garrucha d'aço", 1.000 .000 de virotões, e, confirmando a importância da pirobalística, 200 "bombardas meas", 500 "tiros" e 160 quintais de pólvora. No total, orçava este planeamento em dezoito contos e centro e trinta reis, pelo que, para garantir a sua exequibilidade atempada, se sugeria a breve publicação da convocatória de Cortes (ibidem, pp. 52-56).

${ }^{23}$ Ibidem, pp. 52-53.

${ }^{24}$ GÓIS, Damião de - ob. cit., cap. XLII, p. 105; PINA, Rui de - ob. cit., cap. CLXXIII - CLXXIV, p. 830.

Medievalista online No 19| Janeiro - Junho 2016 (C) IEM - Instituto de Estudos Medievais 7 
tempo do Inverno, "na entrada de Mayo logo seguynte serem em Arronches, per onde acordou d'entrar" ${ }^{25}$. Durante o apetrechamento bélico do exército português temos, uma vez mais, notícia do empenho das Ordens Militares, cuja estrutura operacional e logística a mobilizar parece ter sido relativamente dispendiosa. Ao longo do mês de Março, em Évora, o rei diferiu vários pedidos de autorização de arrendamento de terras à Ordem do Hospital para que pudesse fazer face às despesas na guerra, "visto como pera se rreger lhe he neçessario arrendar as dictas suas commendas" 26 , contando-se entre os beneficiários um cavaleiro, quatro comendadores e o próprio Prior do $\mathrm{Crato}^{27}$.

No final de Maio de 1475, um poderoso exército penetrou em Castela sob o comando de D. Afonso V, fazendo alto em Codiceira e, depois, em Pedraboa, onde foi reforçado por contingentes que atravessaram a Beira. Os cronistas portugueses, Rui de Pina, Garcia de Resende e Damião de Góis, são unânimes quanto aos números do alardo $^{28}$ - a única contagem que dispomos das forças portuguesas - realizado no mesmo dia: "cinquo mil e seis çentos homens de cauallo, e quatorze mil de pé, afora outra gente de seruiço, pages e gente aventureira"29. A consensualidade dos três cronistas confere alguma fiabilidade a estas cifras, mas estamos longe de saber a dimensão do grupo das Ordens Militares, tarefa que pela ausência de fontes se torna praticamente inconclusiva ou conjectural. Podemos, ainda assim, percepcionar em linhas gerais o que numericamente representava o contributo das milícias monástico-militares se tivermos em conta outros dados. Sabemos que, no início do século XV, o conselho de D. João I, ao engendrar uma espécie de exército fixo de defesa de Portugal, atribuiu às Ordens Militares a obrigação de fornecerem 340 das 3.200 lanças previstas para todo o reino (10,6 \% do

\footnotetext{
${ }^{25}$ PINA, Rui de - ob. cit., cap. CLXXIV, p. 830.

${ }^{26}$ FIGUEIREDO, José Anastácio de - Nova História da Militar Ordem de Malta e dos Senhores GrãoPriores della em Portugal: fundada sobre os documentos que só podem supprir, confirmar ou emendar o pouco incerco ou falso que della se acha impresso. 3 vol. Lisboa: Officina de Simão Thaddeo Ferreira, 1800, p. 78.

${ }^{27}$ Os documentos régios dirigidos aos hospitalários com vista a viabilizar a possibilidade de arrendamento de bens da Ordem estão datados, respectivamente: de 4 de Março de 1475, autorizando o comendador de Belver, Álvaro Pires; de 6 de Março, dois documentos, um anuindo ao comendador de Vera Cruz, Pero Gomes, e outro ao de Negroponte, Paio Correia; de 8 de Março, acedendo ao pedido do prior do Hospital, D. Vasco de Ataíde; de 12 de Março, autorizando o comendador do Landal, João Coelho; por último, sabemos do diferimento a um cavaleiro de Pedrógão, de nome Pero. Veja-se: Ibidem, p. 78.

${ }^{28}$ GÓIS, Damião de - ob. cit, cap. L, p. 117; PINA, Rui de - ob. cit., cap. CLXXVII, p. 832; RESENDE, Garcia de - ob. cit., cap. IX, p. 7.

${ }^{29}$ PINA, Rui de - ob. cit., cap. CLXXVII, p. 832
} 
total): Cristo e de Santiago, as milícias mais poderosas, deveriam contribuir com 100 lanças cada, enquanto a Avis caberiam 80 e ao Hospital as restantes 60. Se considerarmos o aumento demográfico na Cristandade desde os finais da primeira metade de Quatrocentos (de que Portugal beneficiou também) ${ }^{30}$, o crescimento dos exércitos de então e a circunstância de, em 1475, se tratar de uma campanha ofensiva em que se apostavam fortes recursos nacionais (e não apenas de forças fixas de defesa do reino), acreditamos que as Ordens Militares portuguesas tenham contribuído com um número substancialmente superior de combatentes ao que foi preconizado ao tempo do rei de Boa Memória ${ }^{31}$.

Mas se acerca da quantidade de combatentes das Ordens Militares são omissas as fontes, idêntica limitação encontramos para conhecermos a sua qualidade marcial. Antes de mais, devemos ter em linha de conta as características de disciplina e obediência inerentes a estas milícias, as quais, transportadas para o combate, resultavam num enorme espírito de grupo com clara simultaneidade e unidade de acção ${ }^{32}$. Quanto ao armamento, não podemos esquecer que, pelos rendimentos do seu património, as Ordens Militares tinham ao seu alcance a aquisição e manutenção de armamento sofisticado, ao ponto de fornecerem mais de $10 \%$ do armamento pesado de Portugal no reinado de D. João $\mathrm{I}^{33}$. Então, a indicação de arneses parece destacar a tradição do combate montado entre as Ordens, pelo que não é ilegítimo supor que na invasão de Castela, em 1475, se tenham evidenciado em contingentes de cavalaria, fosse numa variante mais pesada (a "muy grossa jente d'armas encubertados",34, como surgem designados esses combatentes na Batalha de Toro) com cavaleiro de arnês completo (armadura articulada), vocacionada para o choque, ou até num modelo mais ligeiro, de "genetes", que se adequavam pela mobilidade aos raides e às escaramuças, nas quais

\footnotetext{
${ }^{30}$ DIAS, João José Alves - "A população". in SERRÃO, Joel e MARQUES, A. H. de Oliveira (dir.) Nova História de Portugal. Vol. 5. Lisboa: Editorial Presença, 1999, p. 11

${ }^{31}$ MONTEIRO, João Gouveia - "Organização e formação militares", p. 200.

${ }^{32}$ ALMEIDA, Fortunato de - História da Igreja em Portugal. Vol. 1. Coimbra: Imprensa Académica, 1910-1915, p. 150.

${ }^{33}$ MONTEIRO, João Gouveia - "Organização e formação militares", p. 200.

${ }^{34}$ PINA, Rui de - ob. cit., cap. CXC, p. 844.
} 
sabemos terem participado freires cavaleiros ${ }^{35}$. A par destes guerreiros, não podemos deixar de aduzir aos seus contingentes, como chamou à atenção Miguel Gomes Martins, um número geralmente desconhecido de combatentes mais modestos por si enquadrados, como sargentos e peões, os quais eram recrutados nas localidades sob a jurisdição das Ordens Militares ${ }^{36}$.

Quanto à participação nas operações da campanha comandada por D. Afonso V em Castela, que se iniciou em Maio de 1475 e culminaria em Junho do ano seguinte, temos notícia do seu primeiro combate pela cronística portuguesa durante a segunda metade do mês de Julho de 1475. Chegado a Toro, cuja vila dominou, D. Afonso V cercou o castelo, embora rapidamente se tenha visto entre dois fogos. D. Fernando de Aragão, partindo de Valladolid à frente de uma imponente força que, segundo Damião de Góis, atingiu cerca de 12.000 cavaleiros e de 30.000 infantes $^{37}$ - números considerados inflacionados por Luís Miguel Duarte ${ }^{38}$-, assentou arraial a cerca de meia légua de Toro. Apesar da superioridade numérica, o aragonês não terá atacado por o castelo estar "em todo tam percebido e com estancias tam armado, e affortalezado"39, conforme é corroborado pela cronística castelhana, sendo mesmo obrigado a retirar da sua posição ao fim de uma semana, em parte pela acção dos cavaleiros hospitalários de Diogo Fernandes de Almeida que, "de dia e de noyte" ${ }^{40}$, davam rebates no campo inimigo (quase capturando o próprio D. Fernando) $^{41}$. Tratou-se, à partida, de uma operação desencadeada por uma força móvel, adestrada e disciplinada.

Quanto ao resto da campanha, é notória a tendência dos cronistas para destacarem a acção régia e dos titulares da nobreza, omitindo a participação dos freires cavaleiros. Ainda assim, à falta de luz das fontes, admitimos a sua presença, se não em todas porque não temos dados para o afirmar - pelo menos em muitas das perseguições,

35 DUARTE, Luís Miguel - “1449-1495...”, pp. 349-351; MONTEIRO, João Gouveia - “Castelos e rmamento". in BARATA, Manuel Themudo e TEIXEIRA, Nuno Severiano (dir.) - Nova História Militar de Portugal. Vol. 1, pp. 184-189.

${ }^{36}$ MARTINS, Miguel Gomes - De Ourique a Aljubarrota - A guerra na Idade Média. Lisboa: A Esfera dos Livros, 2011, pp. 28-31.

${ }^{37}$ GÓIS, Damião de - ob. cit., cap.LIIII, pp. 121-122.

${ }^{38}$ DUARTE, Luís Miguel - “1449-1495...”, p. 376.

${ }^{39}$ PINA, Rui de - ob. cit., cap. CLXXIX, p. 834.

${ }^{40}$ Ibidem, cap. CLXXIX, p. 834.

${ }^{41}$ BERNÁLDEZ, Andrés - ob. cit., cap. XVIII, p. 65. 
escaramuças, defesas, tomadas e cercos a praças (por ventura, no de Baltanás ou no de Zamora). Nesta guerra de movimento em Castela, sabemos pela última vez da actuação das milícias monástico-militares na batalha que tantas vezes se evitara e que, a 1 de Março de 1476, se viria ferir na veiga a cinco quilómetros a Poente de Toro e se converteria no combate historiograficamente mais emblemático de toda a guerra. Dividido, grosso modo, o exército português em duas forças, D. Afonso V confiou ao filho o comando da az esquerda - "de menos jente, e porém cortesaã e mui limpa"42 -, junto do qual nos é revelada pela cronística portuguesa a presença de Jorge Correia, comendador do Pinheiro ${ }^{43}$, portanto, um destacado membro da Ordem de Cristo. Sendo o próprio príncipe administrador de duas Ordens Militares (Avis e Santiago), não será de excluir a presença dos respectivos corpos de cavaleiros junto do seu líder, fazendo mesmo sentido que tenham tomado parte na carga que permitiu o desbarato das seis alas castelhanas e a permanência desta força portuguesa no campo ${ }^{44}$.

\section{2. À defesa do reino: as Ordens Militares e a guerra na fronteira}

Muito embora a Guerra da Sucessão de Castela conte momentos militarmente altos entre Maio de 1475 e Junho de 1476, com epicentro na região de Arévalo, Zamora e Toro, há que não descurar uma outra dimensão do conflito que, durante quatro anos, teve lugar por toda a raia luso-castelhana. No que diz respeito a esta frente, sabemos do empenhamento das Ordens Militares radicadas em Portugal, mais uma vez, desde os finais de 1474, aquando da elaboração do referido parecer de guerra em que tomou parte o experiente prior do Hospital. Escrito na iminência do conflito, não por acaso o documento nos ilumina, entre os primeiros pontos, as questões relacionadas com as defesas fixas e o comando militar na "frontaria" 45 àquele tempo.

\footnotetext{
${ }^{42}$ PINA, Rui de - ob. cit., cap. CXC, p. 844.

${ }^{43}$ Ibidem, cap. CXCI, p. 845.

${ }^{44}$ Ibidem, cap. CXCI, pp. 845-848. A propósito da Batalha de Toro, em particular, veja-se: ENCARNAÇÃO, Marcelo Augusto Flores Reis da - A Batalha de Toro. Dissertação de Doutoramento em História Medieval e do Renascimento apresentada à Faculdade de Letras da Universidade do Porto. Porto: [Policopiado], 2011.

${ }^{45}$ CHAVES, Álvaro Lopes de Chaves - ob. cit., p. 52.
} 
"Que o dito senhor [rei] proueja loguo sobre o repairo dos Castellos e fortalezas (...) principalmente da parte do sartam"46. Assim começa o primeiro apelo do triunvirato de conselheiros régios, chamando a atenção para a necessidade de intervenções nas estruturas defensivas raianas que se encontravam sob a alcaidaria da Coroa, dos senhores e, claro estava, das "ordeens". Relativamente aos castelos enquadrados nos dois últimos grupos de detentores, pedia-se ao monarca que respondesse o quanto antes por quem seriam reparados: "a sua custa ou dos que os tiuerem"47. Mostrando conhecimento da arquitectura militar, detalhava-se a prioridade de obras nos "muros, torres, barreiras, portas cisternas", bem como do provimento de "artelharias"48. A proposta de importação, por parte de D. Vasco de Ataíde e dos demais conselheiros, de 100 "bombardas meas" e de 170 quintais de salitre (cerca de 10 toneladas) para os castelos fronteiriços aponta para uma fase de afirmação das armas de fogo nas fortificações. Se tomarmos por fonte iconográfica o Livro das Fortalezas do debuxador Duarte d'Armas ${ }^{49}$, somente três décadas posterior ao conselho de Estremoz, contabilizamos troneiras - um dos elementos caracterizadores da arquitectura militar de transição ${ }^{50}$ provocada pela pirobalística - em 36 dos 55 castelos fronteiriços, ou seja, em $65 \%$.

Em segundo lugar, o prior do Crato, a par do bispo de Évora e do camareiro-mor, pronunciava-se "acerqua de se haverem de ordenar fronteiros-mores em cada huas frontarias do Rejno" ${ }^{\text {51 }}$. Estes oficiais, cujos poderes militares de excepção os sobreporiam aos alcaides dos concelhos, à nobreza e às milícias monástico-militares, só deveriam ser nomeados, na opinião daqueles conselheiros, quando o monarca tomasse uma decisão definitiva quanto ao projecto castelhano, pois se "ouuer de hir compre

\footnotetext{
${ }^{46}$ Ibidem, p. 52.

${ }^{47}$ Ibidem, p. 53.

${ }^{48}$ Ibidem, p. 52.

${ }^{49}$ ARMAS, Duarte de - Livro das Fortalezas. Introdução de Manuel da Silva Castelo Branco. $3^{\text {a }}$ ed. Lisboa: Arquivo Nacional da Torre do Tombo - Edições Inapa, 2006.

${ }^{50}$ Segundo Luís Miguel Duarte, as velhas muralhas e castelos medievais foram, até se alcançar o estilo abaluartado em pleno século XVI, passando nos finais da Idade Média por uma arquitectura militar de transição, que se caracterizava pelo abaixamento das torres, pelo reforço da base das muralhas, pela construção de barbacãs para absorver o tiro rasante da pirobalística, pela execução de fossos ou cavas, pelo reforço ou edificação de torres cilíndricas ou circulares e, claro, pelas aberturas cónicas nas muralhas através das quais as bocas-de-fogo poderiam disparar, as troneiras. Veja-se: DUARTE, Luís Miguel "1449-1495...", pp. 362-363.

${ }^{51}$ CHAVES, Álvaro Lopes de - ob. cit., p. 53.
} 
leuar huns e deixar outros nas frontarias e guarda do Rejno e se não houuer de hir laa hauera mister de prouer acerqua da guarda e deffensão do Rejno por outro modo",52. No caso de a resolução de D. Afonso V vir a ser, como veio, a guerra com Castela, aconselhava-se a imediata nomeação dos fronteiros-mores para que logo seguissem para as regiões raianas correspondentes a superintender o "repairo e deffensão dos castelos, fortalezas e terras",53.

Iniciadas as operações de guerra nos finais de Maio seguinte, o exército português marchava na região de Arévalo, Zamora e Toro, onde D. Afonso V possuía as principais bases de apoio. Conscientes dos recursos e apoios que as tropas afonsinas concentravam, depressa os Reis Católicos procuraram sacudir essa pressão através de ataques de destruição, pilhagem e ocupação de praças na raia portuguesa. É sintomático que em Junho de 1475, como está documentado, D. Fernando e D. Isabel tenham concentrado forças em Ciudad Rodrigo e em Badajoz, dois dos principais eixos de penetração em Portugal. Desenhava-se uma realidade bélica, desencadeada por ambos os contendores ao longo de quatro anos, com consequências desde a raia minhota à algarvia $^{54}$. Neste contexto, os combatentes das Ordens Militares tiveram que se empenhar na guarda dos seus castelos fronteiriços e, decerto, de tomar parte nos exércitos às ordens do príncipe D. João, que, como enfatizou Garcia de Resende, "não se contentua com tão pouca gente, como tinha, defender os Reynos, mas ainda com ella fazia muyta guerra aos enimigos"

Dos vinte e quatro aglomerados, todos fronteiriços ou próximos da fronteira, que D. Afonso V referiu numa carta de 23 de Maio de 1480 como particularmente atingidos durante o conflito, terminado no ano anterior, vinte e dois localizavam-se na Comarca de Entre Tejo e Guadiana ${ }^{56}$. Podemos imaginar a profundidade das cicatrizes

52 Ibidem, pp. 53-54.

${ }^{53}$ Ibidem, pp. 54.

${ }^{54}$ MORENO, Humberto Baquero - "A contenda entre D. Afonso V e os Reis Católicos: incursões castelhanas no solo português de 1475 a 1478”. in Anais - Academia Portuguesa da História. $2^{a}$ Série, 25 (1971), p. 205.

${ }^{55}$ RESENDE, Garcia de - ob.cit., cap. IX, p. 8.

${ }^{56} \mathrm{O}$ citado documento, que consta na Chancelaria de D. Afonso V, encontra-se já transcrito e publicado no seguinte estudo, aludindo às seguintes povoações alentejanas martirizadas pela guerra: Serpa, Moura, Mourão, Monsaraz, Terena, Alandroal, Juromenha, Vila Viçosa, Borba, Olivença, Redondo, Elvas, Campo Maior, Ouguela, Arronches, Alegrete, Portalegre, Marvão, Castelo de Vide, Montalvão, Assumar 
socioeconómicas da guerra naquelas terras quando o monarca justificava a concessão de isenções fiscais pelo "rrecrecer muytos trabalhos, fadigas, perdas e danos", em particular, "aos moradores e lauradores" devastação sobre a produção, as incursões tiveram como alvo os habitantes, que "mujtas vezes erom presos, rresgatados" ${ }^{\prime 58}$, acarretando problemas na agricultura a um ponto tal que, segundo a documentação, as comunidades "nom podiam laurar, nem semear e se semeuam nom colhiam"

A região mais fustigada foi, sem dúvida, a da fronteira do Alto Alentejo, onde as Ordens Militares possuíam domínios importantes e tiveram que se bater pela sua defesa. Enquanto a Ordem de Cristo concentrava o seu património entre o Mondego e o Tejo e a Ordem de Santiago dividia os seus domínios entre o litoral a Sul do Tejo e a fronteira baixo-alentejana e algarvia, as milícias do Hospital e de Avis dominavam vastas áreas na importante fronteira do Alto Alentejo. A Ordem do Hospital, com epicentro na região do Crato, e a Ordem de Avis, com grandes propriedades de Coruche a Elvas e Noudar, viram os seus domínios atacados quer por incursões de saque e pilhagem às vulneráveis aldeias e campos, quer por tomada de praças e escaramuças ${ }^{60}$.

De facto, a fronteira alentejana, onde as Ordens Militares possuíam parte substancial dos seus domínios, compreendia uma importante linha de infiltração em Portugal: a que ligava Badajoz a Elvas, a Estremoz e Évora (praças que podemos considerar de defesa em profundidade ao território), permitindo a progressão no sentido de Lisboa. Os Reis Católicos efectuaram maior pressão em torno daquele eixo, pois era nas regiões da Estremadura e da Andaluzia que encontravam parte substancial dos seus apoiantes, como era o caso da Ordem de Alcântara, que possuía territórios na fronteira de Albuquerque, ou do duque de Medina Sidónia, que exercia uma grande influência ao

e Monforte. Veja-se MORENO, Humberto Baquero - "Os confrontos fronteiriços entre D. Afonso V e os Reis Católicos". in Revista da Faculdade de Letras. Série 2, vol. 10 (1993), pp. 322-324.

${ }^{57}$ Ibidem, p. 322.

${ }^{58}$ Ibidem, p. 323.

${ }^{59}$ Ibidem, p. 323.

${ }^{60}$ FONSECA, Luís Adão da - "Ordens Militares". in AZEVEDO, Carlos Moreira de (dir.) - Dicionário da História Religiosa de Portugal, vol. 3, pp. 337-340; RODRIGUES, Ana Maria S. A. e DUARTE, Luís Miguel - "A Propriedade". in SERRÃO, Joel e MARQUES, A. H. de Oliveira /dir.) - Nova História de Portugal. Vol. 5, p. 104.

Medievalísta online № 19| Janeiro - Junho 2016 () IEM - Instituto de Estudos Medievais 14 
redor de Sevilha. Já a Norte, confinante às Beiras portuguesas, os senhores castelhanos seguiram, tendencialmente, a causa de D. Afonso V e D. Joana, como eram os casos do duque de Arévalo e do marquês de Vilhena, sendo aí mais esporádicos os ataques a Portugal $^{61}$.

Um caso paradigmático foi o da única ocupação registada de uma praça de uma Ordem Militar portuguesa. Tratou-se da tomada de Noudar aos cavaleiros de Avis. Rui de Pina refere vagamente que a operação teve lugar em 1475, "ano em que elRey Dom Afonso entrou em Castella"62, ao passo que Jerónimo de Zurita, mais preciso, aponta para a viragem para o mês de Junho daquele ano ${ }^{63}$, logo após o monarca português ter transposto o Tejo para norte a caminho de Plasência. Então, procurando tirar partido de uma maior vulnerabilidade da fronteira lusa, os Reis Católicos "mandaram gente de guerra que entrou em Portugal, da qual algua fez seu caminho pola fronteira de Badajoz, e tomarão na comarca d'Eluas a villa d'Ouguella, e ha de Noudal"64.

Pouco sabemos das características do exército que se bateu com os combatentes da Ordem de Avis em matéria de composição e de número, para além de se tratar de uma milícia de Sevilha, como sugerem Damião de Góis e Jerónimo de Zurita ${ }^{65}$, e de ser relativamente numeroso, pelo menos em relação à capacidade de resposta portuguesa inclusivamente do próprio príncipe D. João, que se encontraria em Évora quando foi informado da queda de Noudar ${ }^{66}$. Por outro lado, permanece enigmática a quantidade e o armamento dos defensores e das estruturas defensivas de Noudar. Muito embora no Livro das Fortalezas aquela fortificação, globalmente em bom estado, não tenha sido representada com troneiras, a verdade é que se encontraria dotada de vários elementos arquitectónicos tardo-medievais, como era o caso das duas barbacãs, particularmente

${ }^{61}$ SUÁREZ FERNÁNDEZ, Luis - Isabel I, Rainha de Castela. Coimbra: Edições Tenacitas, 2008, pp. 139-157.

${ }^{62}$ PINA, Rui de - ob. cit., cap. CCI, p. 861.

${ }^{63}$ Jerónimo de Zurita indica, com precisão, que a tomada de Noudar se concretizou a 6 de Junho de 1475. Veja-se: ZURITA, Jerónimo de - ob. cit., Libro XIX, cap. XXVIII, p. 240.

${ }^{64}$ GÓIS, Damião de - ob. cit., cap. LII, pp. 119-120.

${ }^{65} \mathrm{O}$ cronista português Damião de Góis não deixa de ser revelador ao referir que, consumada a tomada de Noudar, "ha alcaidaria da qual elRei dom Fernando, e ha rainha donna Isabel deram a Martim de Sepulueda xxiiij de Seuilha" (GÓIS, Damião de - ob. cit., cap. LII, pp. 119-120). Mais explícito, o aragonês Jerónimo de Zurita (ob. cit., Libro XIX, cap. XXVIII, p. 240) indica que a força invasora de Portugal era um exército "de los de Seuilla".

${ }^{66}$ ZURITA, Jerónimo de - ob. cit., Libro XIX, cap. XXVIII, p. 240. 
importantes para absorver o tiro rasante das armas de artilharia ${ }^{67}$. Por fim, o acto da conquista da praça pelos castelhanos não terá acontecido com um violento cerco pois, segundo Pina, a "fortaleza de Noudal que he do meestrado de Avis, per engano e astucia de guerra se tomou" ${ }^{\prime 6}$.

Poderia, naquele contexto, o exército invasor não possuir armamento de cerco ou, pelo menos, logística bastante para suportar um cerco convencional. Noutra perspectiva, poderá este acontecimento indiciar que as Ordens eram, tendencialmente, empenhadas defensoras e possuíam os seus castelos em boas condições de conservação, pelo que o inimigo se viu na contingência de recorrer a estratagemas - longe de sabermos quais e como foram, em concreto, postos em prática (infiltração dissimulada no interior da praça ou escalada nocturna, por exemplo, que tenha levado a abertura de portas). Ainda assim, será legítimo acreditar que, dadas as exigências da guerra, se registasse uma escassez de cavaleiros de Avis no castelo de Noudar; nesse caso, uma guarnição à base de peonagem local, por ventura menos experiente, por alguma lacuna de enquadramento ou de comando não poderá ter permitido o sucesso do ardil adversário ${ }^{69}$

\section{As Ordens Militares castelhanas: vacilando entre os dois partidos}

Nos finais do século XV, conforme sintetizou Miguel Angel Ladero Quesada, as milícias monástico-militares implantadas em Castela - Santiago, Calatrava, Alcântara e S. João (do Hospital) - representavam um enorme potencial social, económico e, claro está, bélico $^{70}$. No seu conjunto, senhoreavam mais de 50.000 quilómetros quadrados de território (compreendiam mais de 400 povoados e 350.000 habitantes); arrecadavam anualmente mais de 250.000 ducados de rendas; quando chamadas às armas, entre

\footnotetext{
${ }^{67}$ ARMAS, Duarte de - ob. cit., desenhos 11 e 12.

${ }^{68}$ PINA, Rui de - ob. cit., cap. CCI, p. 861.

${ }^{69}$ Veja-se, a propósito do castelo de Noudar: COELHO, Adelino de Matos - O castelo de Noudar, fortaleza medieval. Barrancos: Câmara Municipal de Barrancos, 1986.

${ }^{70}$ LADERO QUESADA, Miguel Angel (coord.) - Edad Media. Vol. 2 da Historia Militar de España. Dir. Hugo O’Donnell. Madrid: Laberinto; Ministerio de Defensa, 2010, pp. 224-225.
} 
homens de armas, lanceiros e espingardeiros, mobilizavam facilmente cerca de 5.000 combatentes, isto é, mais de $25 \%$ das forças das "hostes nobiliárias",71.

Durante a Guerra da Sucessão de Castela, as Ordens Militares tornaram-se desde cedo preciosas para ambas as facções. É sintomático que poucas semanas após sobre a entrada de D. Afonso V em Castela, os futuros Reis Católicos, por carta dada em Ávila em 16 de Junho de 1475, se tenham dirigido aos "maestres de las Ordenes, priores e comendadores" nos seguintes moldes: referindo a invasão do rei português, procuravam captar estas organizações para a sua causa e estimular incursões destas sobre Portugal, prometendo "donaçion, pura, perfecta e non revocada, a cada uno de vos, de las villas, e lugares y castillos e fortalezas, que cada uno de vos tomare del dicho reyno" ${ }^{\text {"72 }}$. No contexto político do conflito, as informações acerca das Ordens de S. João do Hospital, de Santiago, de Calatrava e de Alcântara caracterizam-nas, ao nível interno, por várias cisões e, ao mesmo tempo, pela volatilidade de alianças. Capazes das mais heterogéneas operações, do ponto de vista bélico, as Ordens Militares castelhanas destacar-se-iam decisivamente enquanto agressoras do território português e dos senhorios dos apoiantes de D. Afonso V em Castela.

A Ordem de Alcântara ${ }^{73}$, implantada na fronteira extremenha, encontrou-se profundamente dividida durante a Guerra da Sucessão. Sabemos, através do cronista castelhano Andrés Bernáldez, que alguns dos seus elementos se aliaram com o rei de Portugal, como o administrador e duque de Arévalo, D. Álvaro Stuñiga, que numa fase inicial acompanhou militarmente a campanha do Africano, ou o "clavero D. Alonso de Monroy, Maestre que se llamaba de Alcântara"74, que segurou a fortaleza estremenha de Montachez até à assinatura das pazes de Alcáçovas em $1479^{75}$. Mas, na sua

${ }^{71}$ MONTEIRO, João Gouveia - A Guerra em Portugal nos finais da Idade Média. Lisboa: Notícias, 1998, p. 83.

72 TORRE, Antonio de la, SUÁREZ FERNÁNDEZ, Luis - Documentos referentes a las relaciones con Portugal durante el reinado de los Reyes Catolicos. Vol. 1. Valladolid: Gráficas Andrés Martin, 1958, doc. 23, pp. 84-85.

${ }^{73}$ Leia-se, a propósito da Ordem de Alcântara no século XV: LADERO QUESADA, Manuel Fernando "La Orden de Alcántara en el siglo XV. Datos sobre su potencial militar, territorial, económico y demográfico". in En la Espãna Medieval. Estudios en memoria del profesor D. Salvador de Moxó. Vol. 2. Madrid: Universidad Complutense, 1982, pp. 500-541.

${ }_{75}^{74}$ BERNÁLDEZ, Andrés - ob. cit., cap. XVIII, p. 62.

${ }^{75}$ Ibidem, cap. XLI, pp. 117-119. 
generalidade, a milícia, senhora de vastos territórios na zona de Albuquerque, mostrouse uma verdadeira ameaça ao Alentejo, primeiro sob o governo de D. Francisco de Solis e, a partir da viragem para 1477, de D. Juan de Stuñiga, a quem D. Isabel reconheceu a chefia da Ordem ${ }^{76}$.

No início da contenda, temos notícia que os cavaleiros da milícia tomaram a pequena fortaleza raiana de Ouguela, a qual os Reis Católicos deram por mercê em carta de 31 de Julho de 1475 a "don Francisco de Solis, electo de la Orden de Alcantara" porque, afirmavam os monarcas, "com toda lealtad (...) tomastes una villa del dicho reyno, que se dice Vguela" ${ }^{, 77}$. No mesmo dia, animados pela tomada da praça, D. Isabel e D. Fernando notificaram as "ciudades de Coria, Badajoz, Trujillo, Cáceres y Albuquerque" de que haviam nomeado o mesmo mestre de Alcântara para que "faga guerra a fuego e a sangre e todo o mal e daño que pudieren en el Reyno de Portogal”. Naquele documento, ordenavam àquelas cidades que dessem aposentadoria ao exército do mestrado de Alcântara e que o acrescentassem com "toda e qualquier gentes, de cauallo e de pie, e armas e petrechos e mantimientos",78. Em suma, confiava-se à Ordem de Alcântara o enquadramento bélico de um exército, mais ou menos heterogéneo, que então se formava para atacar o território português.

Já em 1476, segundo Rui de Pina, a "Villa d'Alegrette estando o príncipe em Touro foy manhosamente tomada" pelo mestre de Alcântara ${ }^{79}$. A milícia, num facto também confirmado pelas crónicas castelhanas ${ }^{80}$, recorreu a um estratagema e escolheu um momento em que haveria menos defensores nas fronteiras lusas, uma vez que os esforços portugueses se empenhavam em Toro.

No ano seguinte, parece ter sido a vez da Ordem de Alcântara perder praças do seu património pois, como refere a cronística portuguesa, "ouve ho Pryncepe de Pedro Pantoja Cavaleiro Castelhano as fortallezas da Zagalla e Pedra Bõa, que sam do mestrado d'Alcantara, junto com Albuquerque em que pôs seus alcaides e capitaães, e

${ }^{76}$ AYALA MARTÍNEZ, Carlos de - Las órdenes militares hispánicas en la Edad Media (siglos XII-XV). Madrid: Marcial Pons - Latorre Literaria, 2010, p. 754.

${ }^{77}$ TORRE, Antonio de la Torre, SUAREZ FERNANDEZ, Luis - ob. cit., doc. 28, p. 89.

${ }^{78}$ Ibidem, doc. 29, pp. 89-92.

${ }^{79}$ PINA, Rui de - ob. cit., cap. CCI, p. 860.

${ }^{80}$ PULGAR, Fernando del - ob. cit., cap. XXXVIII, p. 124. 
por ellas the deu em Portugal a vila de Santiago de Cacem, que he do mestrado de Santiago", já que interessava ao D. João, líder daquela Ordem em Portugal, o controlo dos castelos da fronteira até ao final do conflito ${ }^{81}$.

Já a Ordem de Santiago ${ }^{82}$, a mais poderosa milícia monástico-militar castelhana, sabemos ter-se dividido em três facções à morte de D. Henrique IV: por um lado, o novo marquês de Vilhena, D. Diego Lopes Pacheco, reclamava a sucessão de seu pai à frente do mestrado, o que contribuiu para a ruptura com D. Isabel na viragem para $1475^{83}$ (segundo o cronista Andrés Bernáldez, este nobre castelhano, um dos principais “joanistas”, intitular-se-ia mestre até se reconciliar com os Reis Católicos em $1477^{84}$ ); por outro, pretendia a chefia dos espatários o conde de Paredes, D. Rodrigo Manrique, comendador de Segura, eleito mestre pelos comendadores que conseguiu reunir no Convento de Uclés ${ }^{85}$; por último, considerava-se mestre legítimo D. Afonso de Cárdenas, comendador-mor de Leão, que havia sido eleito pelos demais comendadores daquela província ${ }^{86}$. A aspiração ao mestrado por estes dois últimos, ambos seguidores da causa de D. Isabel, somente ficaria resolvida pela morte de D. Rodrigo Manrique em Novembro de 1476. Até então, ficamos com a sensação que os Reis Católicos procuraram tirar partido de ambos os pretensos líderes.

Ainda D. Afonso V não tinha entrado em Castela, na primeira metade de 1475, e já os espatários fiéis ao conde de Paredes, segundo Fernando del Pulgar, fustigavam os territórios de D. Diego Lopes Pacheco, evidenciando-se no cerco ao castelo de Alcaraz ${ }^{87}$. Durante esse assédio, segundo Jerónimo de Zurita, os cavaleiros de Santiago resistiram, com sucesso, à tentativa de socorro dos defensores perpetrada por uma força de 300 cavaleiros e 300 peões da milícia de Calatrava, cujo mestre, D. Rodrigo Téllez

\footnotetext{
${ }^{81}$ PINA, Rui de - ob. cit., cap. CCI, p. 861.

${ }^{82}$ No que diz respeito à Ordem de Santiago na centúria de Quatrocentos, torna-se útil a seguinte leitura: PORRAS ARBOLEDAS, Pedro Andrés - La Orden de Santiago en el Siglo XV: la provincia de Castilla. Madrid: Dyckinson, 1997.

${ }^{83}$ PULGAR, Fernando del - ob. cit., cap. XVIII, p. 59; cap. XXV, pp. 79-80; ZURITA, Jerónimo de - ob. cit., Libro XIX, cap. XVIII, p. 226.

${ }^{84}$ BERNÁLDEZ, Andrés - ob. cit., cap. XXVIII, pp. 83-84.

${ }^{85}$ PULGAR, Fernando del $-o b$. cit., cap. XVIII, p. 58.

${ }^{86}$ Ibidem, cap. XVIII, pp. 58-59.

${ }^{87}$ Ibidem, cap. XXXVI, pp. 117-119.
} 
Girón, era primo do marquês de Vilhena ${ }^{88}$. As acções militares dos cavaleiros espatários em torno deste pretendente ao mestrado seriam, de resto, decisivas ao retirarem uma base de apoio importante ao rei de Portugal no interior de Castela. No início de 1476, os moradores de Ocaña, domínio do marquês de Vilhena, trataram com D. Rodrigo Manrique e alçaram-se pelos Reis Católicos, tendo os espatários entrado na vila e combatido os homens de D. Diego Lopes Pacheco. O marquês, sabendo da perda deste território, retirou com as suas forças em defesa do seu território, para prejuízo de D. Afonso $\mathrm{V}$, que combateria em Toro sem o seu apoio ${ }^{89}$.

Por outro lado, pouco após a entrada do monarca português no reino vizinho, sabemos que por carta dada em Ávila, a 20 de Junho de 1475, D. Isabel pediu aos oficiais concelhios da fronteira que apoiassem logística e operacionalmente um exército de espatários comandado por D. Afonso de Cárdenas, designado para fazer guerra a "fuego e sangre" ao reino de Portugal ${ }^{90}$. De facto, este parecia ter sido o principal teatro de operações que lhe destinaram. Morto o conde de Paredes e dirimidas as várias convulsões internas na Ordem, em finais de 1476, o entretanto mestre indiscutível, D. Afonso de Cárdenas ${ }^{91}$, tornava às suas incursões em território português. Através de Damião de Góis, sabemos que, entretanto, "entrou em Portugal bem acompanhado de gente, e encaminhou pola terra dentro xv legoas, e sem achar resistência nenhua se tornou pera Castella" ${ }^{92}$. Tal como atesta o cronista castelhano Fernando del Pulgar, "robó todos los ganados, y taló todo lo que halló dentro del reyno" "93. Noutra acção, datada de 1477, o mestre de Santiago parece ter tido menor sorte: tendo ido "correr as portas D euora", regressava a Castela quando, na zona de Mourão, foi surpreendido por D. Diogo de Castro, o qual, com cerca de 150 lanças, lhe caiu sobre a retaguarda e fez vários cativos ${ }^{94}$.

\footnotetext{
${ }^{88}$ ZURITA, Jerónimo de - ob. cit., Libro XIX, cap. XXVII, p. 239.

${ }^{89}$ PULGAR, Fernando del - ob. cit., cap. LI, pp. 161-162.

90 TORRE, Antonio de la Torre, SUAREZ FERNANDEZ, Luis - ob. cit., doc. 25, pp. 85-87.

${ }^{91}$ RODRÍGUEZ-PICAVEA MATILLA, Enrique - "Los cismas en las órdenes militares ibéricas durante la Edad Media".in En la España Medieval 34 (2011), p. 298.

${ }_{92}$ GÓIS, Damião de - ob. cit., cap. LII, pp. 119-120.

${ }^{93}$ PULGAR, Fernando del - ob. cit., cap. XXXVIII, p. 124.

${ }^{94}$ RESENDE, Garcia de - ob. cit., cap. XVI, pp. 17-18.
} 
Entre as derradeiras acções dos cavaleiros de Santiago de Castela nesta guerra, está registado um combate em campo aberto, conhecido como Batalha de Mérida, "na entrada do ano de myl e quatrocentos e setente e nove", que teve lugar na sequência do pedido de auxílio da Condessa de Medelin a D. Afonso V. O Africano, segundo Rui de Pina, enviou “por Capitam Moor Dom Garcya de Meneses Bispo d'Evora, e com elle por Capitaaes Dom Joam de Meneses seu irmaõ, e Diogo Lopez de Sousa, e Afonso Telez, e outros que fyzeram setecentos de cavalo, sem alguns de pée de pelleja"95. Sabendo da marcha do exército português, o mestre de Santiago, segundo o mesmo cronista, no comando de "mil e trezentos de cavallo, e tres myl homens de pée", esperou o inimigo nas proximidades de Mérida ${ }^{96}$, onde o bateu num breve recontro travado numa planície que terminou na prisão do próprio bispo de Évora ${ }^{97}$. Vencido o combate, e já próximo o fim da guerra, fora ainda ao mestre de Santiago que couberam os cercos aos castelos estremenhos que apoiavam D. Afonso V, tendo ele próprio liderado em pessoa o assédio ao castelo de Medellin ${ }^{98}$. Após a assinatura do Tratado das Alcáçovas de 1479, D. Afonso de Cárdenas continuaria envolvido no cumprimento das pazes ao conduzir e ao receber, da parte castelhana, os penhores das Terçarias de Moura ${ }^{99}$.

A Ordem de S. João será por ventura, neste contexto, aquela que as fontes e os estudos consultados menos iluminam. Das milícias monástico-militares instaladas em Castela, era, nos finais do século $\mathrm{XV}$, a única com raízes fora do espaço ibérico - de resto, a mais antiga - mas, em simultâneo, a de menor expressão naquele reino ${ }^{100}$. Talvez por essa razão, assumiu um papel marcial mais discreto durante a Guerra da Sucessão.

À semelhança da tendência que temos verificado nas demais Ordens Militares, é um dado adquirido que também a milícia de S. João se dividiu. O estudo de Humberto Baquero Moreno e Isabel Vaz de Freitas conclui que o hospitalário Juan de Valenzuela (senhor de Fuentelapeña, Bóveda e Vadillo), que se intitulava prior da Ordem em

\footnotetext{
${ }^{95}$ PINA, Rui de - ob. cit., cap. CCV, pp. 866-867.

${ }^{96}$ Ibidem, cap. CCV, pp. 866-867.

${ }^{97}$ PULGAR, Fernando del - ob. cit., cap. CVII, pp. 371-377.

${ }^{98}$ BERNÁLDEZ, Andrés - ob. cit., cap. XLI, pp. 117-119.

${ }^{99}$ Ibidem, cap. XLII, pp. 120-121.

${ }^{100}$ LADERO QUESADA, Miguel Angel - ob. cit., pp. 259-262.
} 
Castela $^{101}$, se encontrava entre os apoiantes de D. Afonso V na Batalha de Toro. A referência deste cavaleiro, a quem o Africano terá prometido a chefia da milícia, no célebre combate em campo aberto de 1 de Março de 1476 é, desde logo, a única associação conhecida de um hospitalário à causa do monarca português, pelo que cremos que o apoio que lhe foi prestado por parte desta milícia terá sido residual. Já em relação ao bando dos Reis Católicos, as informações sugerem o inverso.

Com os seus domínios nas cercanias de Toledo, os freires cavaleiros de S. João protagonizaram vários ataques sobre os povoados do senhorio do marquês de Vilhena em Novembro de 1475. Segundo Jerónimo de Zurita, “desde el alcáçar de Consuegra" 102 , a casa-mãe dos hospitalários em Castela, as operações eram comandadas pelo próprio prior Álvaro de Stuñiga (filho do duque de Arévalo, com o mesmo nome). $\mathrm{O}$ apoio da cúpula da Ordem de $\mathrm{S}$. João à causa dos Reis Católicos indicia, portanto, um contributo militar expressivo no seio da milícia ${ }^{103}$.

Na mesma base, por carta de 10 de Janeiro de 1476, D. Isabel dirige-se a "Aluaro de Stuñiga, prior de San Juan, del mi Consejo", para que "haga la guerra contra el adversario de Portugal y sus partidarios" ${ }^{, 104}$, numa altura em que D. Afonso V, concentrado em Toro, aguardava pelos reforços do príncipe D. João. Para além da missão confiada, o documento aponta para a mobilização a realizar por aquele que detinha o poder efectivo na Ordem, destacando "sus personas e con sus cauallos e armas, e la gente de pie e con sus ballestras" ${ }^{105}$, confirmando a sua coexistência, àquele tempo, com as armas de fogo. A natureza da missão, com os seus requisitos de recrutamento, sugere uma inquestionável operacionalidade da milícia, que decerto terá continuado a tomar parte em acções bélicas em circunstâncias que desconhecemos.

\footnotetext{
${ }^{101}$ MORENO, Humberto Baquero e FREITAS, Isabel Vaz de - A Corte de D. Afonso V. O Tempo e os Homens. Gijón: Ediciones Trea S. L., 2006, p. 249.

${ }^{102}$ ZURITA, Jerónimo de - ob. cit., Libro XIX, cap. XXXVI, p. 248.

${ }^{103}$ BARQUERO GOÑI, Carlos - "The Hospitallers and the kings of Castille". in The Military Orders. Vol. 3 - History and Heritage. Aldershot: Ashgate Publishing, 2008, p. 237.

${ }^{104}$ TORRE, Antonio de la Torre, SUAREZ FERNANDEZ, Luis - ob. cit., doc. 34, p. 100.

${ }^{105}$ Ibidem, doc. 34, pp. 101-102.
} 
Por fim, terá sido entre os cavaleiros da Ordem de Calatrava ${ }^{106}$, apesar da oposição do conde D. Afonso de Ribagorça ${ }^{107}$, que D. Afonso V conseguiu, numa fase inicial, um apoio mais explícito de entre as milícias monástico-militares castelhanas, mormente através do seu mestre, D. Rodrigo Téllez Girón ${ }^{108}$. Sabemos que este primo do marquês de Vilhena, em Dezembro de 1474, não enviara quaisquer procuradores a jurar fidelidade a D. Isabel ${ }^{109}$ e que, aquando da entrada do rei português em Castela, segundo atestam os cronista Andrés Bernáldez ${ }^{110}$ e Fernado del Pulgar ${ }^{11}$, se apresentou como um dos principais seguidores de D. Joana, sendo referido junto de D. Afonso V aquando do seu casamento em Plasência. É, portanto, provável que os seus combatentes tenham tomado parte nos cercos e escaramuças que o rei português travou ao longo de 1475 entre Zamora e Burgos.

Contudo, a milícia dos freires de Calatrava sofreu como grande condicionante o facto de as suas terras se encontrarem isoladas, nas proximidades de Madrid, tendo os castelos da Ordem sido alvo de frequentes ataques isabelinos, como aquele violento, na viragem para 1476, em que o "mestre de Sanctiago, per mandado delrei dom Fernando fez guerra ao mestre de Calatraua (...) pelo que ho mestre nam pode vir em pessoa, nem mandar sua gente a elrei dom Affonso por ter della necessidade pera guarda de suas terras"112. A par, as acções do intrépido "Clavero don Garcia López de Padilla",113, seguidor do conde de Ribargoça, subtraíram a D. Rodrigo Téllez Girón grandes extensões de "pastos y rentas" ${ }^{\text {, }}$, no dizer de Jerónimo de Zurita. Neste contexto, de acordo com Fernando del Pulgar, o mestrado de Calatrava acusou especialmente a perda da fortaleza de Ciudad

\footnotetext{
${ }^{106}$ A propósito da Ordem de Calatrava nos finais da medievalidade, cf. SOLANO RUIZ, Emma - La Orden de Calatrava en el siglo XV: los señorios castellanos de la Orden en el fin de la Edad Media. Sevilla: Universidad de Sevilla, 1978.

107 O pretendente ao Mestrado de Calatrava D. Afonso, Conde de Ribagorça, era meio-irmão de D. Fernando, o Católico. Veja-se: ZURITA, Jerónimo de - ob. cit., Libro XIX, cap. XXX, p. 241.

108 ÁLVAREZ PALENZUELA, Vicente Ángel - "Una Divina Retribución: la batalla de Toro en la mentalidade castellana". in A guerra e a sociedade na Idade Média. Actas das VI Jornadas lusoespanholas de estudos medievais. 6 a 8 de Novembro de 2008. Vol. 1. Campo Militar de S. Jorge / Porto de Mós / Alcobaça / Batalha: Sociedade Portuguesa de Estudos Medievais, 2009, p. 40.

${ }^{109}$ PULGAR, Fernando del - ob. cit., cap. XXI, p. 66.

${ }^{110}$ BERNÁLDEZ, Andrés - ob. cit., cap. X, pp. 34-35.

${ }^{111}$ PULGAR, Fernando del - ob. cit., cap. XXVIII, p. 94.

${ }^{112}$ GÓIS, Damião de - ob. cit., cap. LVII, p. 126.

${ }^{113}$ PULGAR, Fernando del - ob. cit., cap. XXXVII, p. 121.

${ }^{114}$ ZURITA, Jerónimo de - ob. cit., Libro XIX, cap. XXXI, p. 244.
} 
Real $^{115}$. O Africano, mais apostado em manter as posições no Douro, acabou por deixar de receber reforços significativos daqueles cavaleiros, sem conseguir auxiliar aquele mestrado tão distante. Talvez a falta de apoio do rei português, que não acedia em entrar para o interior do reino, explique mesmo a secessão que se deu naquela Ordem Militar, na qual, acossado pelos constantes e violentos ataques, o seu comendador-mor, Fernán Gómez de Gúzman, rejeitou o mestre vigente na viragem para $1476^{116}$. Fragilizado, não tardou a que D. Rodrigo, para se conservar à frente do mestrado, chegasse a um pacto com D. Isabel e D. Fernando em Maio do mesmo ano, no qual os jovens monarcas não deixaram de impor o seu ascendente sobre a milícia ${ }^{117}$, ao seu serviço nos três anos de conflito seguintes.

\section{Conclusão}

Se o furor da ideia de Cruzada na Península Ibérica no século XII tinha viabilizado a fixação de Ordens Militares, bem como a constituição de outras tantas, fica claro que o papel marcial destas organizações não se resumiu ao período dos grandes avanços cristãos que culminou na centúria de Trezentos na Reconquista. Chegados ao século $\mathrm{XV}$, as monarquias portuguesa e castelhana continuavam a contar com o empenhamento bélico daquelas milícias frente aos inimigos da fé: combatiam em torno das praças marroquinas ${ }^{118}$, no primeiro caso, e vigiavam os seus castelos na fronteira com Granada, no segundo ${ }^{119}$. A Guerra da Sucessão de Castela de 1475-1479 veio, nessa esteira, confirmar a vocação militar das Ordens - que deram mostras de acompanhar a transição bélica - e a centralização política do poder régio sobre as milícias - num processo em que, segundo Luís Filipe Oliveira, o serviço de Deus e o serviço de rei já se confundiam sobremaneira $^{120}$.

\footnotetext{
${ }^{115}$ PULGAR, Fernando del - ob. cit., cap. XLVI, pp. 148-149.

${ }^{116}$ GÓIS, Damião de - ob. cit., cap. LVII, p. 126; SUAREZ FERNANDEZ, Luís - ob. cit., p. 139.

${ }^{117}$ RODRÍGUEZ-PICAVEA, Enrique - "Los cismas en las órdenes...”, pp. 397-398.

118 OLIVEIRA, Luís Filipe - ob. cit., pp. 4-5.

${ }^{119}$ LADERO QUESADA, Miguel Angel - ob. cit., p. 260.

${ }^{120}$ OLIVEIRA, Luís Filipe - ob. cit., p. 3.
} 
Em Portugal, ao tempo da peleja com os Reis Católicos, as Ordens de Avis e de Santiago eram lideradas pelo próprio príncipe herdeiro, a milícia de Cristo por um sobrinho do rei, o duque D. Diogo de Viseu, e a do Hospital por um membro de uma das linhagens mais próximas do monarca, a dos Ataídes. A participação das milícias monástico-militares no diferendo com D. Fernando e D. Isabel foi, portanto, uma inevitabilidade que, de resto, remontou à discussão nas instituições régias para tomar a decisão quanto ao conflito. Aconselhando a preparação do exército, observámos como as Ordens Militares - fruto da sua vida militar activa - eram profundas conhecedoras em matéria de armamento (ofensivo e defensivo), não lhes escapando a importância das armas de fogo. No que toca ao recrutamento, os seus cavaleiros aprestaram-se para responder à convocatória régia - decerto enquadrando outros combatentes dos seus domínios -, acabando por se destacar em várias operações da campanha de 1475-1476, entre as quais a própria Batalha de Toro. Quais os efectivos que representavam os corpos das Ordens Militares na hoste régia? Esta será, por ventura, a grande dúvida neste âmbito, a qual desperta, desde já, a atenção para a necessidade de estudos mais aprofundados sobre o tema.

Quanto à defesa da raia portuguesa, atestam-se as responsabilidades que as milícias monástico-militares conservavam. Como ficou patente antes da eclosão do conflito, as milícias não deixaram de se preocupar com o enquadramento militar das frontarias e com a conservação dos seus castelos nas áreas raianas, onde mais uma vez ficou patente a importância da artilharia. Promoveriam àquele tempo uma arquitectura militar de transição nas suas praças? Certo é que naqueles quatro anos de contenda, os combatentes das Ordens Militares, cujos territórios (mormente no Alentejo) não deixaram de sofrer as cicatrizes socioeconómicas da guerra, se empenharam com maior ou menor sucesso nos combates fronteiriços, como foi o caso da (malograda) defesa do castelo de Noudar em 1475.

No reino de Castela, onde as Ordens Militares vinham representando para a Coroa um expressivo apoio marcial, comprovámos a tendência divisionista das milícias no contexto da disputa do trono castelhano deixado vago por D. Henrique IV em Dezembro de 1474. Esta fractura institucional prendia-se, em grande medida, com o culminar de um processo a que Enrique Rodríguez-Picavea Matilla chamou de 
aristocratização das Ordens ${ }^{121}$, cujos mestres ou pretensos mestres, cada vez mais senhores laicos da confiança régia, percepcionavam aquelas organizações quase como uma extensão dos seus direitos e património. Protagonizando combates em campo aberto, escaramuças, golpes de mão, razias e cercos, as Ordens de Santiago, Calatrava, Alcântara e S. João revelaram-se determinantes na evolução militar da contenda, destacando-se a sua acção ao serviço de D. Isabel - com exércitos seus ou enquadrando outro tipo de forças - no combate aos apoiantes castelhanos de D. Afonso V, cuja sintomática ausência se sentiria na Batalha de Toro, bem como nas entradas em território luso. Cientes da importância do domínio das milícias, não admira que, finda a Guerra da Sucessão, os Reis Católicos se tenham apressado em obter a administração perpétua dos mestrados de Calatrava (1486), Santiago (1493) e Alcântara (1498) para a Coroa $^{122}$.

\section{REFERÊNCIAS BIBLIOGRÁFICAS}

\section{Fontes:}

ARMAS, Duarte de - Livro das Fortalezas. Introdução de Manuel da Silva Castelo Branco. $3^{\mathrm{a}}$ ed. Lisboa: Arquivo Nacional da Torre do Tombo - Edições Inapa, 2006.

BERNALDÉZ, Andrés - Historia de los Reyes Católicos D. Fernando y Doña Isabel escrita por el Bachiller Andrés Bernáldez, Cura que fué la villa de los Palácios, y Capellan de D. Diego Deza, Arzobispo de Sevilla. T. 1. Sevilla: Imprenta que fue de J. M. Geofrin, 1869.

CHAVES, Álvaro Lopes de - Livro de apontamentos, 1438-1489: Códice 443 da Colecção Pombalina da B. N. L. Introd. e transcrição de Anastásia Mestrinho Salgado e Abílio José Salgado. Lisboa: Imprensa Nacional - Casa da Moeda, 1983.

${ }^{121}$ RODRÍGUEZ-PICAVEA MATILLA, Enrique - "El processo de aristocratización de la Orden de Calatrava (siglos XII-XV)". in Hispania Sacra 59 (Julio-Deciembre 2007), p. 494.

${ }^{122}$ LADERO QUESADA, Miguel Angel - ob. cit., p. 260. 
GÓIS, Damião de - Chronica do Prinçipe Dom Ioam. Ed. crítica e comentada de Graça de Almeida Fernandes. Lisboa: Universidade Nova, 1977.

PINA, Rui de - Crónicas de Rui de Pina. Introdução e revisão de M. Lopes de Almeida. Porto: Lello \& Irmão - Editores, 1977.

PULGAR, Fernando del - Crónica de los Reyes Católicos. Edición y estúdio por Juan de Mata Carriazo. Vol. 1. Madrid: Espasa-Calpe, 1943.

RESENDE, Garcia de - Crónica de D. João II e Miscelânea. Ed. conforme a de 1798. Introdução de J. Veríssimo Serrão. Lisboa: Imprensa Nacional - Casa da Moeda, 1991.

TORRE, Antonio de la; SUÁREZ FERNÁNDEZ, Luis - Documentos referentes a las relaciones con Portugal durante el reinado de los Reyes Catolicos. Vol. 1. Valladolid: Gráficas Andrés Martin, 1958.

ZURITA, Jerónimo - Anales de la Corona de Aragon. t. 4. Saragoça: Diego Dormer, Herederos de Pedro Lanaja y Lamarca, 1668.

\section{Estudos:}

ALMEIDA, Fortunato de - História da Igreja em Portugal. Vol. 1. Coimbra: Imprensa Académica, 1910-1915.

ÁLVAREZ PALENZUELA, Vicente Ángel - "Una Divina Retribución: la batalla de Toro en la mentalidade castellana". in A guerra e a sociedade na Idade Média. Actas das VI Jornadas luso-espanholas de estudos medievais. 6 a 8 de Novembro de 2008. Vol. 1. Campo Militar de S. Jorge / Porto de Mós / Alcobaça / Batalha: Sociedade Portuguesa de Estudos Medievais, 2009, pp. 35-55.

ARAÚJO, Inês Meira - As tapeçarias de Pastrana: uma iconografia da guerra. Tese de Mestrado em História de Arte, Património e Teoria do Restauro apresentada à Faculdade de Letras da Universidade de Lisboa. Lisboa: [s. n.], 2012. 
As Ordens Militares em combate nos finais da Idade Média: o caso da Guerra da Sucessão de Castela (I475-1479)

- António Carlos Martins Costa

AYALA MARTÍNEZ, Carlos de - Las órdenes militares hispánicas en la Edad Media (siglos XII-XV). Madrid: Marcial Pons / Latorre Literaria, 2010.

AYALA MARTínEZ, Carlos, NOVOA PORTELA, Feliciano (dir.) - As Ordens Militares na Europa Medieval. Trad. Daniel Gouveia. Lisboa: Chaves Ferreira, 2005.

BARATA, Manuel Themudo e TEIXEIRA, Nuno Severiano (dir.) - Nova História Militar de Portugal. Vol. 1. Mem Martins: Círculo de Leitores, 2003.

BARQUERO GOÑI, Carlos - "The Hospitallers and the kings of Castile in the Fourteenth and Fifteenth Centuries". in The Military Orders. Vol. 3, History and Heritage. Aldershot: Ashgate Publishing, 2008, pp. 235-240.

COELHO, Adelino de Matos - O castelo de Noudar, fortaleza medieval. Barrancos: Câmara Municipal de Barrancos, 1986.

CONTAMINE, Philippe - La guerre au Moyen Age. $6^{\mathrm{a}}$ ed. Paris: Presses Universitaires de France, 2012.

COSTA, António Carlos Martins - A Batalha de Toro e as relações entre Portugal e Castela: dimensões políticas e militares na segunda metade do século XV. Dissertação de Mestrado em História Medieval apresentada à Faculdade de Letras da Universidade de Lisboa. Lisboa: [Policopiado], 2011.

DIAS, João José Alves - “A população". in SERRÃO, Joel e MARQUES, A. H. de Oliveira (dir.) - Nova História de Portugal. Vol. 5. Lisboa: Editorial Presença, 1999, pp. 11-52.

DIAS, João José Alves (coord.) - Portugal do Renascimento à Crise Dinástica. Vol. V da Nova Nova História de Portugal. Dir. Joel SERRÃO e A. H. de Oliveira MARQUES. Lisboa: Editorial Presença, 1999.

DUARTE, Luís Miguel - “1449-1495: o triunfo da pólvora”. in BARATA, Manuel Themudo e TEIXEIRA, Nuno Severiano (dir.) - Nova História Militar de Portugal. Vol. 1. Mem Martins: Círculo de Leitores, 2003, pp. 347-391. 
ENCARNAÇÃO, Marcelo Augusto Flores Reis da - A Batalha de Toro. Dissertação de Doutoramento em História Medieval e do Renascimento apresentada à Faculdade de Letras da Universidade do Porto. Porto: [Policopiado], 2011.

FERNANDES, Isabel Cristina (coord) - Ordens Militares: guerra, religião, poder $e$ cultura. Actas do III Encontro sobre Ordens Militares. 2 vol. Lisboa / Palmela: Edições Colibri / Câmara Municipal de Palmela, 1999.

FIGUEIREDO, José Anastácio de - Nova História da Militar Ordem de Malta e dos Senhores Grão-Priores della em Portugal: fundada sobre os documentos que só podem supprir, confirmar ou emendar o pouco incerco ou falso que della se acha impresso. 3 vols. Lisboa: Officina de Simão Thaddeo Ferreira, 1800.

FONSECA, Luís Adão da - D. João II. [Lisboa]: Círculo de Leitores, 2005.

FONSECA, Luís Adão da - "Ordens Militares”. in AZEVEDO, Carlos Moreira (dir.) Dicionário da História Religiosa de Portugal. Vol. 3. Lisboa: Círculo de Leitores, 2001, pp. 334-345.

FOREY, Alan - "The Military Orders and the Spanish Reconquest in twelfth and thirtheenth centuries". in Traditio 40 (1984), pp. 197-234.

GOMES, Saúl António - D. Afonso V, o africano. Rio de Mouro: Círculo de Leitores, 2006.

JOSSERAND, Philippe - "Un corps d'armée spécialisé au service de la Reconquête. Les ordres militaires dans le royaume de Castille (1252-1369)". in Bulletin de la Société Archéologique et Historique de Nantes et de Loire-Atlantique 137 (2002), pp. 193-214.

LADERO QUESADA, Manuel Fernando - "La Orden de Alcántara en el siglo XV. Datos sobre su potencial militar, territorial, económico y demográfico". in En la Espãna Medieval. Estudios en memoria del profesor D. Salvador de Moxó. Vol. 2. Madrid: Universidad Complutense, 1982, pp. 500-541.

LADERO QUESADA, Miguel Ángel (coord.) - Edad Media. Vol. 2 da Historia Militar de España. Dir. Hugo O’Donnell. Madrid: Laberinto - Ministerio de Defensa, 2010. 
LADERO QUESADA, Miguel Ángel - Historia de España. Dir. de Lara Hernández. T. 4 - De la crisis medieval al Renacimiento (siglos XIV-XV). 2a ed.. Barcelona: Editorial Planeta, 1989.

MARTINS, Maria Odete Banha da Fonseca Sequeira - Poder e sociedade: a duquesa de Beja. Tese de Doutoramento em História Medieval apresentada à Faculdade de Letras da Universidade de Lisboa. Lisboa: [Policopiado], 2011.

MARTINS, Miguel Gomes - De Ourique a Aljubarrota - A guerra na Idade Média. Lisboa: A Esfera dos Livros, 2011.

MONTEIRO, João Gouveia - "Castelos e armamento". in BARATA, Manuel Themudo e TEIXEIRA, Nuno Severiano (dir.) - Nova História Militar de Portugal. Vol. 1. Mem Martins: Círculo de Leitores, 2003, pp. 164-191.

MONTEIRO, João Gouveia - A Guerra em Portugal nos finais da Idade Média. Lisboa: Notícias, 1998.

MONTEIRO, João Gouveia - "Organização e formação militares". in BARATA, Manuel Themudo e TEIXEIRA, Nuno Severiano (dir.) - Nova História Militar de Portugal. Vol. 1. Mem Martins: Círculo de Leitores, 2003, pp. 192-215.

MORENO, Humberto Baquero - "A contenda entre D. Afonso V e os Reis Católicos: incursões castelhanas no solo português de 1475 a 1478". in Anais - Academia Portuguesa da História. $2^{\text {a }}$ Série, 25 (1971), pp. 297-324.

MORENO, Humberto Baquero - "Os confrontos fronteiriços entre D. Afonso V e os Reis Católicos”. in Revista da Faculdade de Letras. Porto. Série 2, vol. 10 (1993), pp. 103-116.

MORENO, Humberto Baquero e FREITAS, Isabel Vaz de - A Corte de D. Afonso $V$. $O$ Tempo e os Homens. Gijón: Ediciones Trea S. L., 2006.

O’DONNELL, Hugo (dir.) - Historia Militar de España. Vol. 2 - Edad Media. Coord. Miguel Angel Ladero Quesada. Madrid: Laberinto / Ministerio de Defensa, 2010. 
As Ordens Militares em combate nos finais da Idade Média: o caso da Guerra da Sucessão de Castela (1475-1479)

- António Carlos Martins Costa

OLIVEIRA, Luís Filipe - "Apresentação de Tese A Coroa, os Mestres e os Comendadores: as Ordens Militares de Avis e de Santiago (1330-1449). Tese de Doutoramento em História Medieval". Medievalista [online]. № 5 (Dezembro 2008), Disponível em: www2.fcsh.unl.pt/iem/medievalista/MEDIEVALISTA5/medievalistaoliveira.html

PIMENTA, Maria Cristina - “As Ordens de Avis e de Santiago na baixa Idade Média: o governo de D. Jorge". in Militarium Ordinum Analecta 5 (2001).

PORRAS ARBOLEDAS, Pedro Andrés - La Orden de Santiago en el Siglo XV: la provincia de Castilla. Madrid: Dyckinson, 1997.

RODRIGUES, Ana Maria S. A. e DUARTE, Luís Miguel - “A propriedade”. in SERRÃO, Joel e MARQUES, A. H. de Oliveira (dir.) - Nova História de Portugal. Vol. 5. Lisboa: Editorial Presença, 1999, pp. 83-160.

RODRÍGUEZ-PICAVEA MATILLA, Enrique - "Los cismas en las órdenes militares ibéricas durante la Edad Media”. in En la España Medieval 34 (2011), pp. 277-306.

RODRÍGUEZ-PICAVEA MATILLA, Enrique - "El processo de aristocratización de la Orden de Calatrava (siglos XII-XV)”. in Hispania Sacra 59 (Julio-Deciembre 2007), pp. 493-535.

SOLANO RUIZ, Emma - La Orden de Calatrava en el siglo XV: los señorios castellanos de la Orden en el fin de la Edad Media. Sevilla: Universidad de Sevilla, 1978.

SOUSA, Bernardo Vasconcelos e RAMOS, Rui - História de Portugal. $3^{\mathrm{a}}$ ed.. Lisboa: A Esfera dos Livros, 2009.

SUÁREZ FERNÁNDEZ, Luis - Isabel I, Rainha de Castela. Coimbra: Edições Tenacitas, 2008.

VASCONCELlOS, António Maria Falcão Pestana de - Nobreza e Ordens Militares. Relações sociais e de poder (séculos XIV a XVI). 2 vols.. Dissertação de Doutoramento 
As Ordens Militares em combate nos finais da Idade Média: o caso da Guerra da Sucessão de Castela (1475-1479)

- António Carlos Martins Costa

em História Medieval e do Renascimento apresentada à Faculdade de Letras da Universidade do Porto. Porto: [Policopiado], 2008.

\section{COMO CITAR ESTE ARTIGO}

Referência electrónica:

COSTA, António Carlos Martins - "As Ordens Militares em combate nos finais da Idade Média: o caso da Guerra da Sucessão de Castela (1475-1479)". Medievalista [Em linha]. No 19 (Janeiro - Junho 2016). [Consultado dd.mm.aaaa]. Disponível em http://www2.fcsh.unl.pt/iem/medievalista/MEDIEVALISTA19/ costa1907.html ISSN 1646-740X.

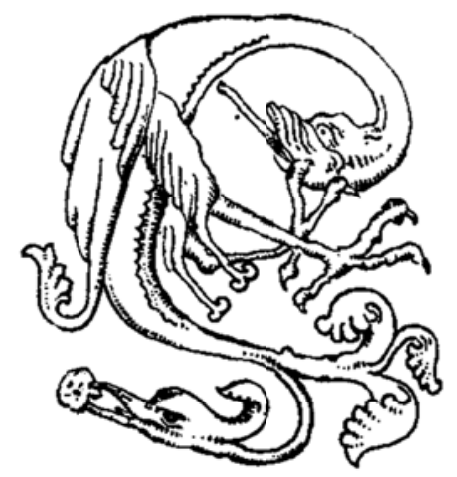

Medievalista online № 19| Janeiro - Junho 2016 (C) IEM - Instituto de Estudos Medievais 32 www2.fcsh.unl.pt/iem/medievalista 